\title{
INHIBITION OF R-FACTOR TRANSFER AND PHAGE INFECTION BY REQUINOMYCIN
}

\author{
Makoto Hori, Kenji Takemoto \& Shizue Watanabe \\ Showa College of Pharmaceutical Sciences, \\ Tsurumaki 5-1-8, Setagaya-ku, Tokyo, Japan \\ Marie Umezawa \& Hamao Umezawa \\ Institute of Microbial Chemistry, \\ Kamiosaki 3-14-23, Shinagawa-ku, Tokyo, Japan
}

(Received for publication May 19, 1972)

To be effective in inhibiting R-factor transfer (between Escherichia coli strains) and infection of $E$. coli with phage $f 2$, requinomycin must be present at the time of initiation of both events. Delayed addition of requinomycin showed no or slight inhibition. No direct effect of requinomycin on phage $\mathrm{f} 2$ or E. coli strains employed was observed. The intact cell surface of E. coli must be impermeable to requinomycin as shown by the fact that DNA synthesis by toluene-treated E. coli cells (permeability modified) was markedly inhibited by requinomycin, in contrast to its ineffectiveness on intact $E$.coli cells. Therefore, requinomycin probably acts without penetrating the cells. Probable mechanism of action is discussed.

R-Factors which determine resistance to a wide range of antibiotics are transmitted between enteric bacteria by conjugation, ${ }^{1,2)}$. In a preceding paper we reported that a new anthracycline antibiotic requinomycin blocked $\mathrm{R}$-factor transfer at concentrations which did not inhibit the growth of $E$. $\mathrm{coli}^{3}$. Since requinomycin had originally been screened for anti-phage activity, we became interested in learning if there is some biological process(es) common to both $\mathrm{R}$-factor transfer and phage infection. As we shall report in the present paper, it seems that requinomycin exerts these effects by binding reversibly to some component (s) of the cell surface.

\section{Materials and Methods}

Anti-phage activity: The time sensitivity to requinomycin was determined as follows: E. coli S-26 was grown in Polypeptone broth at $37^{\circ} \mathrm{C}$ under shaking until an O.D. of 0.18 at $600 \mathrm{~m} \mu$ was reached. From the cell suspension, $1.7 \mathrm{ml}$ portions were distributed into small test tubes which were placed in a $37^{\circ} \mathrm{C}$ bath at minute "zero" and incubated under shaking. At minute $5,10,15,20$ or 30 , one tube for each run received $0.2 \mathrm{ml}$ of $200 \mu \mathrm{g} /$ $\mathrm{ml}$ of requinomycin solution (or $0.85 \% \mathrm{NaCl}$ solution for a control run), while at minute 10 , each tube received $0.1 \mathrm{ml}$ suspension of phage $\mathrm{f} 2\left(10^{8} \mathrm{pfu} \mathrm{u}^{*}\right)$. Incubation was terminated at minute 110 by chilling and the mixtures were serially diluted with $0.85 \% \mathrm{NaCl}-2 \mathrm{mM}$ $\mathrm{CaCl}_{2}$. One-tenth $\mathrm{ml}$ portions of the diluted suspensions were titrated for $\mathrm{pfu}$ using E.coli S-26 as an indicator strain by the pour plate method.

Possible inactivation of phage $\mathrm{f} 2$ by requinomycin was examined as follows: Phage

* plaque forming unit 
f $2\left(2 \times 10^{\circ}\right.$ pfu $)$ were suspended in $2 \mathrm{ml}$ of $0.85 \% \mathrm{NaCl}-2 \mathrm{mM} \mathrm{CaCl}_{2}$ and incubated at $37^{\circ} \mathrm{C}$ for 60 minutes under shaking in the presence or absence of $100 \mu \mathrm{g} / \mathrm{ml}$ of requinomycin. After chilling, each mixture was serially diluted and $0.1 \mathrm{ml}$ portions were titrated for pfu.

Inhibition of R-factor trasfer: E.coli $\mathrm{K}-12\left(\mathrm{~T}^{-}\right) \mathrm{R} 1629^{4)}$ as a donor strain and E.coli $\mathrm{K}-12$ as a recipient strain were grown separately in nutrient broth at $37^{\circ} \mathrm{C}$ under shaking. When the cultures reached an O.D. of 0.2 at $600 \mathrm{~m} \mu, 0.9 \mathrm{ml}$ portions withdrawn from each culture were mixed in Erlenmeyer flasks of $30 \mathrm{ml}$ volume (the time of mixing will be referred to as "minute 0") and incubation was initiated under gentle shaking at $37^{\circ} \mathrm{C}$. At minute 0,30 or 60 , an appropriate flask received $0.2 \mathrm{ml}$ of $500 \mu \mathrm{g} / \mathrm{m} 1$ of requinomycin solution (or $0.85 \% \mathrm{NaCl}$ solution for a control run) and incubation was continued through minute 90. After chilling, the mixtures were serially diluted with $0.85 \% \mathrm{NaCl}$ solution and 0.1 $\mathrm{ml}$ portions were submitted to counting total viable cells and $\mathrm{R}^{+}$recipient cells (recipient cells which acquired drug resistance by conjugation) on plates of nutrient agar and on plates of minimal agar (see below) supplemented with $70 \mu \mathrm{g} / \mathrm{ml}$ of kanamycin sulfate, respectively. Minimal agar consisted of $\mathrm{K}_{2} \mathrm{HPO}_{4} 1.05 \%, \mathrm{KH}_{2} \mathrm{PO}_{4} 0.45 \%, \mathrm{MgSO}_{4} \cdot 7 \mathrm{H}_{2} \mathrm{O} 0.005 \%$, $\left(\mathrm{NH}_{4}\right)_{2}-$ $\mathrm{SO}_{4} 0.1 \%$, Na-citrate $0.045 \%$, glucose $0.2 \%$, agar $1.5 \%$ (bottom layer) and $0.6 \%$ (overlayer), and water.

Elimination of R-factor: An assay mixture contained, in $5 \mathrm{ml}$ of nutrient broth, $4 \times$ $10^{8}$ cells of E. coli $\mathrm{K}-12 \mathrm{ML} 1630^{4)}$ and $500 \mu \mathrm{g}$ of requinomycin (no requinomycin in a control run). After incubation at $37^{\circ} \mathrm{C}$ for 15 hours, each mixture was 10 -fold serially diluted and $0.1 \mathrm{ml}$ portions were submitted to counting total viable cells and $\mathrm{R}^{+}$cells as described above.

DNA synthesis by toluenized E. coli cells: Experiments were conducted according to Moses and Richardson ${ }^{5)}$. E. coli $\mathrm{S}-26$ were grown in $\mathrm{CG}$-medium** at $37^{\circ} \mathrm{C}$ under shaking until a density of $7 \times 10^{8}$ cells $/ \mathrm{ml}$ was reached. Cells were collected by centrifugation, suspended in $1 / 10$ of the culture volume of cold $0.05 \mathrm{M}$ potassium phosphate buffer at $\mathrm{pH}$ 7.4, containing toluene at $1 \%(\mathrm{v} / \mathrm{v})$, and incubated at $37^{\circ} \mathrm{C}$ for 10 minutes under shaking. The cells were collected by centrifugation in a refrigerated centrifuge, washed with $0.05 \mathrm{M}$ potassium phosphate buffer by suspension and centrifugation, suspended in $1 / 10$ of the culture volume of $0.05 \mathrm{M}$ potassium phosphate buffer and stored at $-60^{\circ} \mathrm{C}$ until used. A reaction mixture $(0.3 \mathrm{ml})$ consisted of $70 \mathrm{~mm}$ potassium phosphate (for a final $\mathrm{pH} 7.4$ ), $13 \mathrm{mM} \mathrm{MgCl}_{2}$, $1.3 \mathrm{~mm}$ ATP, $33 \mu \mathrm{M}$ each $3 \mathrm{dXTP's}, 33 \mu \mathrm{M}{ }^{3} \mathrm{H}-\mathrm{TTP}(0.1 \mu \mathrm{Ci}), 1.5 \times 10^{8}$ of toluene-treated cells, and a desired amount of requinomycin. The mixtures were incubated at $37^{\circ} \mathrm{C}$ for 30 minutes and the reaction was terminated by adding $2 \mathrm{ml}$ of ice-cold $10 \%$ trichloroacetic acid $-0.1 \mathrm{M}$ pyrophosphoric acid solution (TCA-PPi). Insoluble materials of each mixture were then filtered on a Whatman GF/C disk (2.4 cm diameter) and washed on the filter 3 times with ice-cold TCA-PPi. The paper disks were dried, placed in counting vials with scintillation solution (toluene-PPO system), and counted in a Beckman liquid scintillation counter.

\section{Results}

Anti-phage Activity

Time Sensitivity to Requinomycin

Requinomycin was added to the host-cell suspension before, at or after the time of infection of phage $f 2$. As shown in Fig. 1, the latest effective time of addition of requinomycin was found to be 5 minutes after infection. Later additions showed no protection. Thus requino-

Fig. 1. Time sensitivity to requinomycin in the course of phage $f 2$ infection

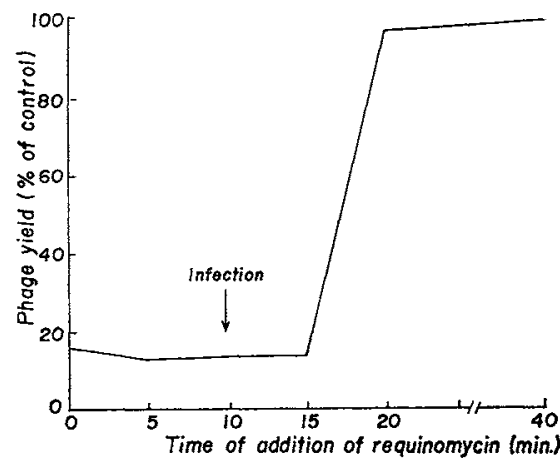


mycin possibly inactivates phage particles or inhibits some early process of phage infection such as adsorption to pili or introduction of phage RNA into host cells through the pili. Requinomycin does not inhibit later processes involved in phage production. As we have

Table 1. Direct effect of requinomycin on free phage $f 2$

\begin{tabular}{c|c}
\hline $\begin{array}{c}\text { Concentration of } \\
\text { requinomycin } \\
(\mu \mathrm{g} / \mathrm{m} 1)\end{array}$ & Number of plaques \\
\hline 0 (control) & $1.10 \times 10^{9}$ \\
100 & $1.16 \times 10^{9}$ \\
\hline
\end{tabular}
reported in a preceding paper, if requinomycin was added 10 minutes before infection at concentrations of $100 \mu \mathrm{g} / \mathrm{ml}, 10 \mu \mathrm{g} / \mathrm{ml}$ and $1 \mu \mathrm{g} / \mathrm{ml}$, it inhibited phage production by $95 \%, 85 \%$ and $38 \%$, respectively, under similar conditions. It has been confirmed by a separate experiment that requinomycin does not inhibit the growth of the host cells at concentrations as high as $100 \mu \mathrm{g} / \mathrm{ml}$.

Does Requinomycin Inactivate Phage Particles?

Even after a prolonged incubation of a phage suspension in the presence of 100 $\mu \mathrm{g} / \mathrm{ml}$ of requinomycin, the phage titer of the solution, assayed after dilutions, was found unchanged as shown in Table 1. This result ruled out the possibility that requinomycin inactivates phage particles. Therefore, if requinomycin has any direct effect on phage particles, the effect should be of reversible nature since it can be abolished upon dilution.

\section{Inhibition of R-Factor Transfer}

Time Sensitivity to Requinomycin

In the preceding paper ${ }^{3)}$ we reported that requinomycin inhibited $\mathrm{R}$-factor transfer by $92 \%, 58 \%$ and $19 \%$ at concentrations of $50 \mu \mathrm{g} / \mathrm{ml}, 25 \mu \mathrm{g} / \mathrm{ml}$ and $5 \mu \mathrm{g} / \mathrm{ml}$, respectively, if the antibiotic was present at the time of mixing of donor and recipient cells. Under these conditions, requinomycin did not affect the viability of either donor or recipient cells. In the present experiment, the time of addition of requinomycin was varied during the course of $\mathrm{R}$-factor transfer. As shown in Fig. 2, requinomycin was very effective only when it was present throughout the incubation period. Later additions of requinomycin showed lesser inhibition. These results suggested that requinomycin inhibits the transfer process per se but has no effect on

Table 2. Examination for curing of $R$-factors by requinomycin

Fig. 2. Time sensitivity to requinomyci $=$ in the course of $\mathrm{R}$-factor transfer

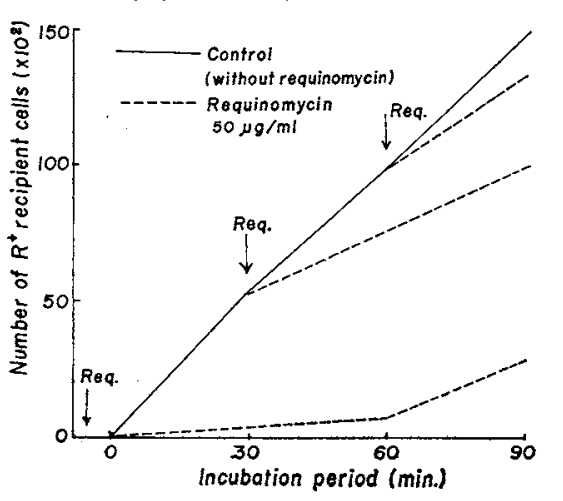

\begin{tabular}{|c|c|c|}
\hline & Total cells & $\begin{array}{c}\text { Cells resistant } \\
\text { to } 50 \mathrm{\mu g} / \mathrm{ml} \text { of } \\
\text { kanamycin sulfate }\end{array}$ \\
\hline Control & $8.7 \times 10^{8}(\mathrm{cells} / \mathrm{ml})$ & $8.9 \times 10^{8}$ \\
\hline $\begin{array}{l}\text { + Requinomycin } \\
(100 \mathrm{\mu g} / \mathrm{ml})\end{array}$ & $4.1 \times 10^{8}$ & $3.6 \times 10^{8}$ \\
\hline
\end{tabular}

Runs were triplicated and averaged.

The experiment was conducted as given under Materials and Methods. Under these conditions, $100 \mu \mathrm{g} / \mathrm{ml}$ of requinomycin appeared somewhat growth-inhibitory to this strain of $E$.coli; total cells in +requinomycin run were fewer than those in control run $\left(4.1 \times 10^{8}\right.$ vs. $8.7 \times$ $\left.1^{3}\right)$. This is in contrast to other observations that requinomycin showed no effect on the doubling time of any $E$.coli strain (based on turbidity measurement or cell counting) at a concentration as high as $100 \mu \mathrm{g} / \mathrm{ml}$. This inconsistency may be due to difference either in growth conditions or the period of drug treatment. However, the conclusion drawn from this experiment is not affected by this inconsistency because most cells $\left(3.6 \times 10^{8}\right.$ in $\left.4.1 \times 10^{8}\right)$ retained resistance to kanamycin after the treatment with requinomycin. 
cells which acquired drug-resistance. This point was made clearer by another experiment which examined possible elimination of $\mathrm{R}-$ factors (curing) by requinomycin. As shown in Table 2, requinomycin slightly converted the resistant cells to antibiotic sensitivity even after a prolonged treatment, indicating that requinomycin has no curing effect. In this respect, the mode of action of requinomycin is different from that of acriflavin ${ }^{2)}$, an intercalating dye. mycin, an inhibitor of cell wall synthesis, preferentially inhibited the growth of drug-resistant cells which were derepressed for sex-pili formation. Requinomycin does not have this effect, either.

\section{Impermeability of $E$. coli Cell Surface to Requinomycin}

\section{Inhibition by Requinomycin of DNA Synthesis in Toluenized E. coli Cells}

Considering the ineffectiveness of requinomycin to any $E$. coli strain used for the present study, the simplest explanation for the requinomycin action would be that requinomycin binds to the cell surface in a specific manner to modify the function of sex-pilus or its receptor but not to interfere with membrane transport of essential metabolites. At present, exact nature of the target molecule to which requinomycin binds is not known. However, it must localize on the cell surface because of the following observation. As shown in Table 3, requinomycin markedly inhibits DNA synthesis in toluenized E. coli cells in contrast to its ineffectiveness to intact cells. Interaction with DNA template could be characteristic to anthracycline antibiotics $^{7-9)}$. This result strongly suggests that the intact cell surface of $E$.coli is impermeable to requinomycin.

\section{Discussion}

Sex-pili are essential structures for both adsorption of phage $f 2$ and conjugation ${ }^{10)}$, and therefore, sex-pili or their receptors are suspected to be the binding sites of requinomycin. However, it has been reported recently that levallorphan, a structural analogue of morphine, also inhibited both phage infection and $\mathrm{R}$-factor transfer ${ }^{11,12)}$ and the latter action was thought to be due to inhibition of mating pair formation. Requinomycin may work in an analogous way. Considering dissimilarity in structure, it is unlikely that requinomycin and levallorphan can share the same target molecule of the cell surface. Accordingly, these effects could be a common result of various changes in the conformation of the cell surface.

\section{References}

1) Akiba, T.; K. Koyama, T. Ishiki, S. Kimura \& T. Fugushrma: On the mechanism of the development of multiple drug-resistant clones of Shigella. Jap. J. Microb. $4: 219 \sim 227,1960$

2) WATANABE, T.: Infective heredity of multiple drug sesistance in bacteria. Bacteriol. Rev. 27: $87 \sim 116,1963$

3) Hori, M.; K. Takemoto, I. Homma, T. Takeuchi, S. Kondo, M. Hamada, T. Okazaki, Y.Okami \& H. UMEZAWA : Requinomycin, an inhibitor of $\mathrm{R}$-factor transfer: Isolation, characterization and properties. J. Antibiotics $25: 393 \sim 399,1972$

4) OKanishi, M.; S. Kondo, R. Utahara \& H. Umezawa: Phosphorylation and inactivation of 
aminoglycosidic antibiotics by $E$. coli carrying $\mathrm{R}$ factor. J. Antibiotics $21: 13 \sim 21,1968$

5) Moses, R. E. \& C. C. Richardson: Replication and repair of DNA in cells of Escherichia coli treated with toluene. Proc. Natl. Acad. Sci. U. S. $67: 674 \sim 681,1970$

6) Iyoвe, S.; S. Mrtsuashi \& H. UMezazwa : Relationship between sex-pili formation and macarbomycin sensitivity in Escherichia coli. J. Bacteriol. 108:946 947, 1971

7) WARING, M.: Variation of the supercoils in closed circular DNA by binding of antibiotics and drugs. Evidence for molecular models involving intercalation. J. Mol. Biol. $54: 247 \sim 279,1970$

8) NAGAI, K.; N. TANAKA \& H. UMEzAWA: Inhibition of nucleic acid biosynthesis in cell-free systems of Escherichia coli B by pluramycin. J. Biochem. $67: 655 \sim 660,1970$

9) Tsukada, I.; M. Hamada, H. UMEZawa, M. HorI \& H. Hayashi : Neopluramycin, an inhibitor of nucleic acid synthesis. J. Antibiotics $24: 189 \sim 196,1971$

10) Brinton, C. C., Jr.; P. Gemski \& J. CarnahaN : A new type of bacterial pilus genetically controlled by the fertility factor of $E$. coli $\mathrm{K} 12$ and its role in chromosome transfer. Proc. Nat1. Acad. Sci. U.S. $52: 776 \sim 782,1964$

11) RAAB, C. \& R. Röschenthaler : Inhibition of adsorption and replication of the RNA-phage MS-2 in Escherichia coli C 3000 by levallorphan. Biochem. Biophys. Res. Commun. 41: 1429 1436, 1970

12) Löser, R.; P. L. Boquet \& R. Rösohenthaler : Inhibition of R-factor transfer by levallorphan. Biochem. Biophys. Res. Commun. 45: 204 211, 1971 